\title{
Immobilization of Aspergillus oryzae $\beta$ galactosidase on concanavalin A-layered calcium alginate-cellulose beads and its application in lactose hydrolysis in continuous spiral bed reactors
}

\author{
Shakeel Ahmed Ansari, Qayyum Husain* \\ Aligarh Muslim University, Department of Biochemistry, Faculty of Life Sciences, Aligarh-202002, India \\ "Corresponding author: e-mail: qayyumbiochem@gmail.com
}

\begin{abstract}
In this study, Aspergillus oryzae $\beta$ galactosidase was immobilized on concanavalin A layered calcium alginate-cellulose beads as a bioaffinity support. Immobilized enzyme showed a remarkable broadening in temperature-activity profiles as compared to the native enzyme and exhibited $65 \%$ activity in the presence of $5 \%$ galactose. Michaelis constant $\left(\mathrm{K}_{\mathrm{m}}\right)$ was $2.57 \mathrm{mM}$ and $5.38 \mathrm{mM}$ for the free and the immobilized $\beta$ galactosidase, respectively. Crosslinked $\beta$ galactosidase showed greater catalytic activity in the presence of $\mathrm{Mg}^{2+}$ and was more stable during storage at $4^{\circ} \mathrm{C}$ for 6 weeks. Immobilized enzyme hydrolyzed $67 \%$ lactose in milk in $8 \mathrm{~h}$ and $85 \%$ lactose in whey in $9 \mathrm{~h}$ in the stirred batch process at $50^{\circ} \mathrm{C}$. The continuous hydrolysis of lactose by crosslinked $\beta$ galactosidase in spiral bed reactor exhibited $93 \%$ and $88 \%$ hydrolysis of lactose at flow rate of $20 \mathrm{ml} / \mathrm{h}$ and $30 \mathrm{ml} / \mathrm{h}$, after 1 month operation, respectively.
\end{abstract}

Keywords: $\beta$ galactosidase. Immobilization. Cellulose-alginate. Concanavalin A. Spiral bed reactor. Lactose hydrolysis.

\section{INTRODUCTION}

$\beta$ Galactosidase (3.2.1.23) is a hydrolytic enzyme that catalyzes the breakdown of lactose into glucose and galactose. It is found in plants, animals and microorganisms. This enzyme has been employed in producing lactose free whey, milk and milk products ${ }^{1}$. Hydrolysis of lactose improves the product's sweetness and makes milk consumption much easier for the people suffering from lactose intolerance and increases the quality of the product in dairy industry ${ }^{2,3}$.

The widespread industrial application of enzymes is often hampered by their lack of long term operational stability and shelf-storage life, their cumbersome recovery and re-use. These drawbacks can generally be overcome by immobilization of enzymes, and a major challenge in industrial biocatalysis is the development of stable, robust and preferably insoluble biocatalysts ${ }^{\mathbf{4}, 5}$. Immobilized biocatalyst can be reused several times and provides several benefits, especially in the food technologies, including easy separation from reaction mixture, no contamination of the product by the enzyme, operational and long term stability, continuous processing and multienzyme reaction systems ${ }^{6}$. Several methods utilize the affinity of biomolecules and ligands for immobilization of enzymes which are widely used in constructing enzyme based analytical devices and other applications ${ }^{7-9}$. The suitability of support and the method of immobilization varies from enzyme to enzyme and their intended use, and therefore a separate optimization of each system is essential ${ }^{10,11}$.

In the present study, an attempt was made to immobilize Aspergillus oryzae $\beta$ galactosidase on a bioaffinity support, Concanavalin A (Con A) layered calcium alginate-cellulose beads. The stability of immobilized $\beta$ galactosidase (I $\beta \mathrm{G})$ has been studied against various physical and chemical denaturants, and compared with its soluble counterpart. Immobilized $\beta$ galactosidase was used in a stirred batch process for the hydrolysis of lactose from milk and whey at various temperatures and in a spiral bed reactor for continuous hydrolysis of lactose in solution.

\section{MATERIALS AND METHODS}

\begin{abstract}
Materials
Aspergillus oryzae $\beta$ galactosidase (3.2.1.23), $\alpha$-methyl $\beta$-D-glucopyranoside, glucose oxidase, o-dianisidine $\mathrm{HCl}$ and glucose were obtained from Sigma Chem. Co. (St. Louis, MO, USA). Cellulose was purchased from Titan Biotech (Rajasthan, India), Peroxidase, glutaraldehyde and $o$-nitrophenyl $\beta$-D-galactopyranoside (ONPG) were obtained from SRL Chemicals (Mumbai, India). Sodium alginate was the product of Koch-Light Lab. (Colnbrook, UK). Jack bean meal was procured from Loba Chemical Co. (Mumbai, India). All other chemicals and reagents used were of analytical grade and used without purification.
\end{abstract}

\section{Preparation of calcium alginate-cellulose beads}

An aqueous mixture of sodium alginate $(2.5 \%, \mathrm{w} / \mathrm{v})$ and cellulose $(2.5 \%, \mathrm{w} / \mathrm{v})$ was prepared and the resulting mixture was slowly extruded as droplets through a $5.0 \mathrm{ml}$ syringe with attached needle no. 20 into a 0.2 $\mathrm{M}$ calcium chloride solution. The formation of calcium alginate-cellulose beads was instantaneous and the solution was gently stirred for $2 \mathrm{~h}$. The beads were then washed and stored in $0.1 \mathrm{M}$ sodium acetate buffer, $\mathrm{pH}$ 4.6 at $4^{\circ} \mathrm{C}$, until further use.

\section{Binding of Con A on calcium alginate-cellulose beads}

Jack bean extract $(10 \%, \mathrm{w} / \mathrm{v})$ was prepared by adding $5.0 \mathrm{~g}$ of jack bean meal to $50 \mathrm{ml}$ of $0.1 \mathrm{M}$ Tris- $\mathrm{HCl}$ buffer, $\mathrm{pH}$ 6.2. Calcium alginate-cellulose beads $(500$ beads) were incubated overnight with jack bean extract $(25 \mathrm{ml})$ containing Con A at room temperature with slow stirring on a magnetic stirrer. Con A bound calcium alginate-cellulose beads were washed thrice with $0.1 \mathrm{M}$ sodium acetate buffer, $\mathrm{pH}$ 4.6. 


\section{Adsorption of $\beta$ galactosidase on Con A layered calcium alginate-cellulose beads}

Con A layered calcium alginate-cellulose beads were incubated with $\beta$ galactosidase $(2250 \mathrm{U})$ overnight at $32^{\circ} \mathrm{C}$, with slow stirring. The unbound enzyme was removed by repeated washing with $0.1 \mathrm{M}$ sodium acetate buffer, $\mathrm{pH}$ 4.6.

\section{Crosslinking of immobilized $\boldsymbol{\beta}$ galactosidase}

$\beta$ Galactosidase immobilized on the surface of Con A layered calcium alginate-cellulose beads was suspended in $0.1 \mathrm{M}$ sodium acetate buffer, $\mathrm{pH} 4.6$ for $2 \mathrm{~h}$ at $4^{\circ} \mathrm{C}$. Adsorbed enzyme preparation was crosslinked by $0.5 \%(\mathrm{v} / \mathrm{v})$ glutaraldehyde for $2 \mathrm{~h}$ at $4^{\circ} \mathrm{C}$. Finally the immobilized enzyme was incubated with $0.01 \%(\mathrm{v} / \mathrm{v})$ ethanolamine for $90 \mathrm{~min}$ at $30^{\circ} \mathrm{C}$ to stop crosslinking. The integrity of the crosslinked immobilized enzyme was examined by incubating the beads in $1.0 \mathrm{M} \alpha$-methyl$\beta$-D-glucopyranoside for $2 \mathrm{~h}$ at room temperature.

\section{Effect of temperature}

The activity of the soluble and immobilized $\beta$ galactosidase $(20 \lambda)$ was assayed in $0.1 \mathrm{M}$ sodium acetate buffer, $\mathrm{pH} 4.6$ at various temperatures $\left(20-80^{\circ} \mathrm{C}\right)$ for $15 \mathrm{~min}$. The activity obtained at $50^{\circ} \mathrm{C}$ was considered as control (100\%) for the calculation of remaining percent activity at different temperatures.

Soluble and immobilized $\beta$ galactosidase preparations were incubated at $60^{\circ} \mathrm{C}$ in $0.1 \mathrm{M}$ sodium acetate buffer, $\mathrm{pH} 4.6$ for varying times. Aliquots of each preparation $(20 \lambda)$ were taken at indicated time intervals and chilled quickly in crushed ice for $5 \mathrm{~min}$. The enzyme was brought at room temperature. The enzyme activity without incubation at $60^{\circ} \mathrm{C}$ was taken as control (100\%) for the calculation of the remaining percent activity.

\section{Effect of galactose and $\mathrm{MgCl}_{2}$}

The activity of soluble and immobilized $\beta$ galactosidase $(20 \lambda)$ was independently measured in the presence of increasing concentrations of galactose $/ \mathrm{MgCl}_{2}(1.0-5.0 \%$, $\mathrm{w} / \mathrm{v}$ ) in $0.1 \mathrm{M}$ sodium acetate buffer, $\mathrm{pH} 4.6$ for $1 \mathrm{~h}$ at $37^{\circ} \mathrm{C}$. The activity of the enzyme without added galactose $/ \mathrm{MgCl}_{2}$ was considered as control (100\%) for the calculation of the remaining percent activity.

\section{Storage stability}

Soluble and the immobilized $\beta$ galactosidase preparations were stored at $4^{\circ} \mathrm{C}$ in $0.1 \mathrm{M}$ sodium acetate buffer, $\mathrm{pH} 4.6$ for over 6 weeks. The aliquots from each preparation $(20 \lambda)$ were taken in triplicates at the gap of 10 days and were then analyzed for the remaining enzyme activity. The activity determined on the first day was taken as control $(100 \%)$ for the calculation of remaining percent activity.

\section{Hydrolysis of milk lactose in batch process}

The cold milk was skimmed by centrifugation at $8000 \times \mathrm{g}$ for $20 \mathrm{~min}$. The fat layer was removed from the milk and stored at $4^{\circ} \mathrm{C}$ for further use. Skimmed milk $(500 \mathrm{ml})$ was independently treated with soluble and immobilized $\beta$ galactosidase $(250 \mathrm{U})$ in a stirred batch process at $50^{\circ} \mathrm{C}$ and $60^{\circ} \mathrm{C}$. The aliquots of $250 \mu \mathrm{l}$ were taken at indicated time intervals for $10 \mathrm{~h}$. The hydrolysis of lac- tose was estimated by glucose oxidase-peroxidase assay procedure as described by Ansari and Husain (2010) ${ }^{\mathbf{3}}$.

\section{Hydrolysis of whey lactose in batch process}

Skimmed milk was acidified by $\mathrm{HCl}$ until the $\mathrm{pH}$ reached to 4.8 and casein was removed by centrifugation. Whey $(500 \mathrm{ml})$ was separately treated with soluble and immobilized $\beta$ galactosidase (125 U) in a stirred batch process at $50^{\circ} \mathrm{C}$ and $60^{\circ} \mathrm{C}$. The aliquots of $250 \mu$ l were taken out at indicated times and hydrolysis of lactose was estimated using a procedure described by Ansari and Husain $(2010)^{\mathbf{3}}$.

\section{Hydrolysis of lactose in spiral bed reactors}

A spiral column $(70 \times 1.5 \mathrm{~cm})$ filled with immobilized $\beta$ galactosidase $(2520 \mathrm{U})$ was used for the continuous hydrolysis of lactose in solution for 6 weeks. Lactose $(0.1 \mathrm{M})$ dissolved in $0.1 \mathrm{M}$ sodium acetate buffer, $\mathrm{pH}$ 4.6 containing $0.001 \mathrm{M}$ sodium azide was passed through two independent columns with flow rates of $20 \mathrm{ml} / \mathrm{h}$ and $30 \mathrm{ml} / \mathrm{h}$ at room temperature $\left(32^{\circ} \mathrm{C}\right)$. After a gap of 5 days, the samples were collected and analyzed for the hydrolysis of lactose according to the procedure described by Ansari and Husain $(2010)^{3}$.

\section{Glucose estimation}

Glucose released from lactose hydrolysis was monitored using a glucose oxidase-peroxidase coupled assay procedure according to the procedure described by Ansari and Husain $(2010)^{3}$.

\section{Assay of $\beta$ galactosidase}

The hydrolytic activity of $\beta$ galactosidase was determined by measuring the release of $o$-nitrophenol from ONPG at $405 \mathrm{~nm}$. The reaction was performed by continuous shaking in an assay volume of $2.0 \mathrm{~mL}$ containing $1.7 \mathrm{ml}$ of $0.1 \mathrm{M}$ sodium acetate buffer, $\mathrm{pH} 4.6,2.0 \mathrm{U} \beta$ galactosidase and $0.2 \mathrm{ml}$ of $20 \mathrm{mM}$ ONPG. The reaction was stopped by adding $2.0 \mathrm{ml}$ of $2.0 \mathrm{~N}$ sodium carbonate solution and product ( $O$-nitrophenol) formation was measured spectrophotometrically at $405 \mathrm{~nm}$.

One unit $(1.0 \mathrm{U})$ of $\beta$ galactosidase activity is defined as the amount of enzyme that liberates $1.0 \mu$ mole of $o$-nitrophenol $\left(\varepsilon_{\mathrm{m}}=4500 \mathrm{~L} / \mathrm{mol} / \mathrm{cm}\right)$ per min under standard assay conditions according to the procedure described by Ansari and Husain (2010) ${ }^{\mathbf{3}}$.

\section{Estimation of protein}

Protein concentration was determined by the dye binding method ${ }^{\mathbf{1 2}}$.

\section{Statistical analysis}

Each value represents the mean for three independent experiments performed in triplicates, with average standard deviation $<5 \%$. The data expressed in various studies were plotted using Sigma Plot-9 and expressed with standard deviation of error $( \pm)$. A student's t-test was used to examine statistically significant differences. The analysis of variance was performed using ANOVA, $\mathrm{P}$ values $<0.05$ were considered statistically significant. 


\section{RESULTS AND DISCUSSION}

Cellulose and alginate have been independently used by several workers to immobilize enzymes. Cellulose is an inexpensive and easily available matrix. It is widely used as an enzyme immobilization material due to its unique hydrophilic characteristics, relatively high chemicapability ${ }^{13}$. The use of sodium alginate has also been reported for immobilizing and microencapsulating enzymes, cell organelles, plants and animal cells ${ }^{14}$. However, these supports have some limitations like compact packing of cellulose in the reactor affects the flow rate of the column or sometimes block the reactor completely. Although calcium alginate beads have been used for the entrapment of enzymes, but they are not normally used as their large pore size results in enzyme leakage ${ }^{15}$. To overcome this problem, we developed a hybrid gel of calcium alginate-cellulose beads which were layered with Con A. $\beta$ galactosidase from Aspergillus oryzae was then immobilized on Con A layered support.

\section{Immobilization of $\boldsymbol{\beta}$ galactosidase}

In order to prevent the desorption of the enzyme from the surface of beads, adsorbed enzyme was crosslinked by glutaraldehyde. Crosslinking decreased the enzyme activity from $78 \%$ to $70 \%$ (Table 1). It has earlier been reported that while crosslinking of enzyme by glutaraldehyde prevented desorption of the enzyme, the activity of the enzyme was decreased slightly ${ }^{16}$. It is a well-known fact that the crosslinking of enzymes by bi-functional or multi-functional agents enhanced thermal stability due to the formation of several linkages between enzyme and support ${ }^{17}$.

\section{Effect of temperature}

The temperature-optima for both the soluble and immobilized $\beta$ galactosidase preparations were same at $50^{\circ} \mathrm{C}$. However, the immobilized $\beta$ galactosidase showed greater enzyme activity at higher and lower temperatures as compared to its soluble counterpart (Fig 1a). Such enhanced stability was brought about by the immobilization process, which resulted in the formation of molecular cage around the protein molecules (enzyme) thereby enhancing the thermal stability of the immobilized enzyme ${ }^{18}$. Fig $1 \mathrm{~b}$ illustrates the thermal denaturation of soluble and immobilized $\beta$ galactosidase. The immobilized enzyme retained $93 \%$ of the initial activity after $30 \mathrm{~min}$ exposure at $60^{\circ} \mathrm{C}$ while the soluble enzyme lost $40 \%$ activity under similar incubation conditions. The temperature tolerance of the immobilized enzyme increased due to diffusional affects where the reaction velocity is more likely to be diffusion limited, so that improvements in thermal diffusion would correspondingly result in proportionately higher cal stability and remarkable environmental protecting

reaction rates. Bayramoglu et al. (2007) has also shown that $\beta$ galactosidase from Escherichia coli immobilized on magnetic poly beads led to an increase in its stability when incubated at high temperatures ${ }^{\mathbf{1 9}}$. The immobilized enzyme could work in harsh environmental conditions with less activity loss than the soluble $\beta$ galactosidase.

\section{Effect of magnesium chloride and galactose}

Several workers have investigated that galactose is one of the end product of $\beta$ galactosidase catalyzed hydrolysis of lactose and it competitively inhibited the activity of the enzyme ${ }^{20,21}$. Incubation of the soluble $\beta$ galactosidase with $5.0 \%$ galactose for $1 \mathrm{~h}$ at $37^{\circ} \mathrm{C}$ resulted in a significant loss of $71 \%$ activity while the immobilized $\beta$ galactosidase retained over $65 \%$ of the original enzyme activity during such exposure. The immobilized $\beta$ galactosidase was significantly more resistant to inhibition mediated by galactose as compared to the free enzyme. Nevertheless, it had been reported earlier that $\mathrm{Mg}^{+2}$ ions are important for the activity of $\beta$ galactosidase. Thus, the effect of $\mathrm{MgCl}_{2}$ was monitored on the activity of soluble and the immobilized enzyme (Fig 1c). It was observed that at $5 \% \mathrm{MgCl}_{2}$, the activity of the soluble $\beta$ galactosidase decreased while the immobilized enzyme exhibited an enhancement in the activity upto $135 \%$. Sutendra et al. (2007) had observed that E. coli $\beta$ galactosidase has several metal binding sites particularly $\mathrm{Mg}^{+2}$ binding site which bring about an increase in enzyme activity ${ }^{22}$.

\section{Storage stability}

The storage stability of the soluble and immobilized $\beta$ galactosidase has been shown in Fig 1d. The immobilized enzyme retained $80 \%$ of the initial enzyme activity after 6 weeks of storage at $4^{\circ} \mathrm{C}$ while the soluble $\beta$ galactosidase exhibited only $56 \%$ of the original activity after similar storage. The generally observed higher stability of $\beta$ galactosidase may be related to the specific and strong binding of enzyme with bioaffinity support which prevented the unfolding/denaturation of enzyme upon long storage.

\section{Kinetic properties}

Table 2 shows that the immobilization of the enzyme resulted in an increase in " $\mathrm{Km}$ " and a decrease in "Vmax" value. Mass transfer resistance, electrostatic and steric effects may have caused the increase in "Km" value after immobilization. Mass transfer resistance appears to be significant for macromolecular substrates

Table 2. Influence of immobilization on the kinetic constants

\begin{tabular}{l|c|c|}
\hline Derivative & $\mathrm{K}_{\mathrm{m}}(\mathrm{mM})$ & $\mathrm{V}_{\max }(\mathrm{mM} / \mathrm{min})$ \\
\hline Soluble $\beta$ galactosidase & $2.57 \pm 0.48^{+}$ & $0.48 \pm 0.75^{\prime}$ \\
\hline Immobilized $\beta$ galactosidase & $5.38 \pm 0.31^{*}$ & $0.38 \pm 0.42^{\prime \prime}$ \\
\hline
\end{tabular}

Table 1. $\beta$ galactosidase immobilized on Con A layered calcium alginate-cellulose beads

\begin{tabular}{|c|c|c|c|c|c|}
\hline \multirow{2}{*}{ Enzyme preparation } & \multirow{2}{*}{$\begin{array}{l}\text { Enzyme activity } \\
\text { loaded, } X(U)\end{array}$} & \multirow{2}{*}{$\begin{array}{l}\text { Enzyme activity in } \\
\text { washes, } Y(U)\end{array}$} & \multicolumn{2}{|c|}{$\begin{array}{l}\text { Activity bound/g cellulose- } \\
\text { alginate beads }\end{array}$} & \multirow{2}{*}{$\begin{array}{c}\text { Activity yield } \\
(\%) \\
\text { B/A x100 }\end{array}$} \\
\hline & & & $\begin{array}{c}\text { Theoretical } \\
(X-Y)=A\end{array}$ & Actual=B & \\
\hline $\begin{array}{l}\text { Enzyme adsorbed on the surface of } \\
\text { beads }\end{array}$ & 2250 & 831 & 1419 & 1106 & $78 \pm 0.93^{*}$ \\
\hline $\begin{array}{l}\text { Enzyme adsorbed on the surface of } \\
\text { beads and crosslinked }\end{array}$ & 1106 & 0 & 1106 & 774 & $70 \pm 0.55^{\prime \prime}$ \\
\hline
\end{tabular}

"P-values $<0.03$ with respect to crosslinked $\beta$ galactosidase* 

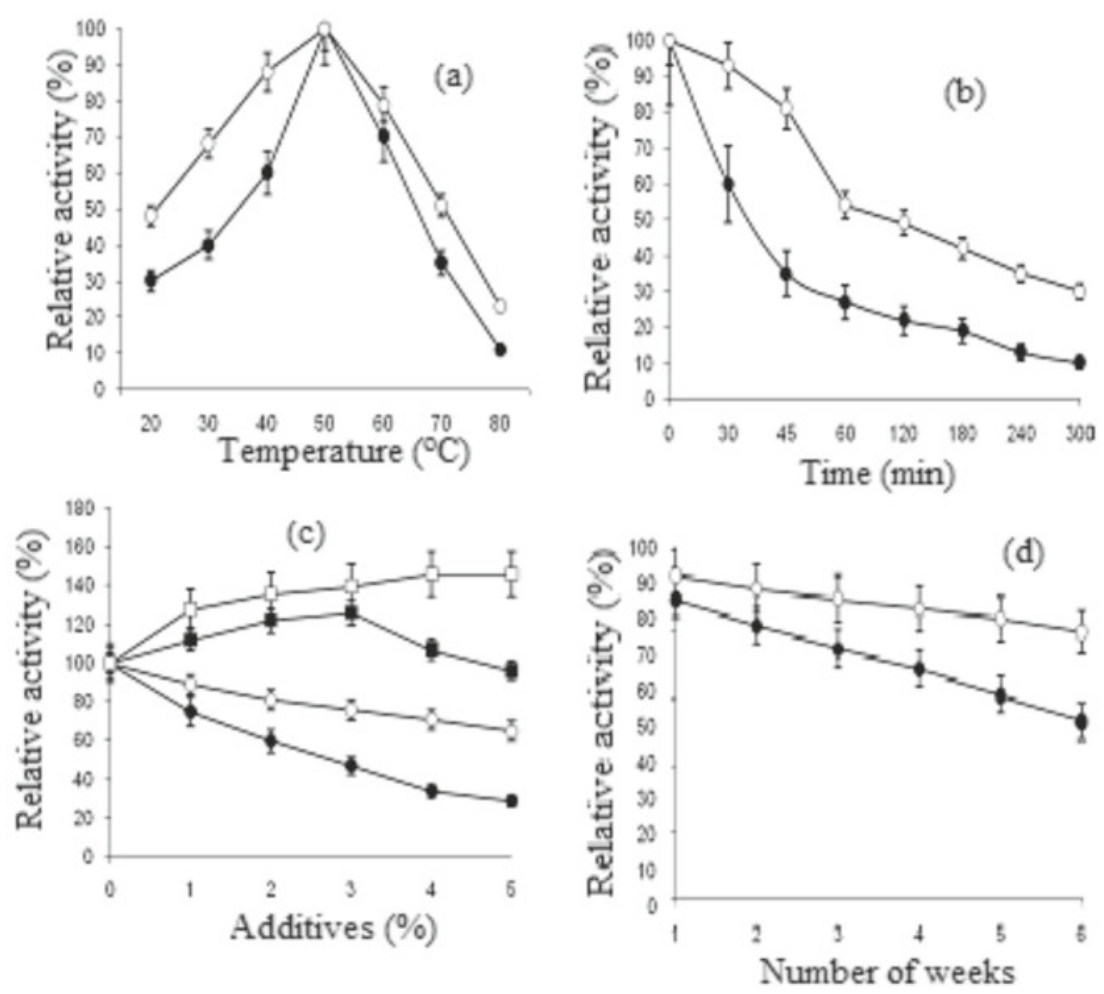

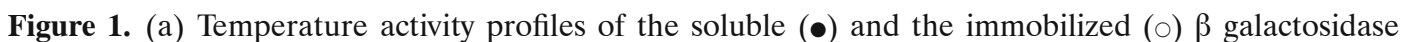

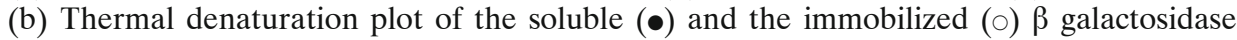

(c) Effect of galactose on the soluble $(\bullet)$ and the immobilized (॰) $\beta$ galactosidase, and $\mathrm{MgCl}_{2}$ on soluble (घ) and immobilized ( $\square$ ) $\beta$ galactosidase

(d) Storage stability of the soluble (•) and the immobilized (०) $\beta$ galactosidase

such as ONPG because the substrate must contact the enzyme adsorbed on the surface of cellulose-alginate beads efficiently. Greater "Km" value may have been attributable to enzyme active sites being less accessible to the substrate than in free solution ${ }^{23}$. Nevertheless, immobilization of $\beta$ galactosidase may also have reduced its ability to undergo conformational changes that are intrinsic to enzyme-substrate interaction, thereby resulting in a noticeable decrease in "Vmax" value for the immobilized enzyme. The increase in "Km" values and decrease in "Vmax" values for the immobilized enzyme seen here are in agreement with the observations of other researchers who conducted work on the immobilized $\beta$ galactosidase $\mathrm{e}^{24,25}$.

\section{Lactose hydrolysis from milk and whey}

Table 3 describes the hydrolysis of lactose from milk and whey by soluble and immobilized $\beta$ galactosidase for various times. It was observed that immobilized enzyme hydrolyzed $67 \%$ and $85 \%$ lactose from milk and whey, respectively after $10 \mathrm{~h}$ at $50^{\circ} \mathrm{C}$ (Table 3 ). The efficiency of lactose hydrolysis in milk and whey by the immobilized enzyme was found to be several folds higher than that mentioned in the earlier work ${ }^{26,27}$. The greater efficiency of the immobilized $\beta$ galactosidase in hydrolyzing lactose from whey compared to milk lactose has been explained by a difference in $\mathrm{pH}$ between the tests, that is, $\mathrm{pH}$ 4.5-5.0 for whey and $\mathrm{pH}$ 6.5-6.8 for milk. Aspergillus

Table 3. Hydrolysis of lactose in milk/whey by the soluble and the immobilized $\beta$ galactosidase in a batch process at $50^{\circ} \mathrm{C} / 60^{\circ} \mathrm{C}$

\begin{tabular}{|c|c|c|c|c|c|c|c|c|}
\hline \multirow{4}{*}{ Time $(\mathrm{h})$} & \multicolumn{8}{|c|}{ Lactose hydrolysis (\%) } \\
\hline & \multicolumn{4}{|c|}{$50^{\circ} \mathrm{C}$} & \multicolumn{4}{|c|}{$60^{\circ} \mathrm{C}$} \\
\hline & \multicolumn{2}{|c|}{ Milk } & \multicolumn{2}{|c|}{ Whey } & \multicolumn{2}{|c|}{ Milk } & \multicolumn{2}{|c|}{ Whey } \\
\hline & $S \beta G$ & $I \beta G$ & $S \beta G$ & $I \beta G$ & $S \beta G$ & $I \beta G$ & $I \beta G$ & $S \beta G$ \\
\hline 1 & $10 \pm 0.25^{+}$ & $8 \pm 0.30^{*}$ & $16 \pm 0.39^{++}$ & $12 \pm 0.18^{\star *}$ & $8 \pm 0.39$ & $5 \pm 0.40^{\#}$ & $13 \pm 0.48^{\prime \prime}$ & $9 \pm 0.22^{\# \#}$ \\
\hline 2 & $17 \pm 0.35^{+}$ & $20 \pm 0.49^{*}$ & $25 \pm 0.31^{++}$ & $31 \pm 0.52^{* *}$ & $12 \pm 0.54^{\prime}$ & $19 \pm 0.48^{\#}$ & $21 \pm 0.69^{\prime \prime}$ & $25 \pm 0.40^{\#}$ \\
\hline 3 & $25 \pm 0.11^{+}$ & $36 \pm 0.59^{\star}$ & $31 \pm 0.79^{++}$ & $48 \pm 0.47^{\star *}$ & $17 \pm 0.39^{\prime}$ & $27 \pm 0.51^{\#}$ & $27 \pm 0.10^{\prime \prime}$ & $41 \pm 0.51^{\text {\# }}$ \\
\hline 4 & $37 \pm 0.65^{+}$ & $51 \pm 0.57^{*}$ & $42 \pm 0.51^{++}$ & $59 \pm 0.39^{* *}$ & $26 \pm 0.62^{\prime}$ & $38 \pm 0.38^{\#}$ & $34 \pm 0.29^{\prime \prime}$ & $49 \pm 0.29^{\#}$ \\
\hline 5 & $44 \pm 0.49^{+}$ & $55 \pm 0.37^{*}$ & $49 \pm 0.49^{++}$ & $65 \pm 0.49^{\star *}$ & $35 \pm 0.79^{\prime}$ & $47 \pm 0.62^{\#}$ & $40 \pm 0.82^{1 /}$ & $56 \pm 0.48^{\#}$ \\
\hline 6 & $49 \pm 0.73^{+}$ & $61 \pm 0.21^{*}$ & $57 \pm 0.56^{++}$ & $70 \pm 0.19^{* *}$ & $40 \pm 0.39^{\prime}$ & $54 \pm 0.82^{\#}$ & $46 \pm 0.90^{\prime \prime}$ & $63 \pm 0.56^{\#}$ \\
\hline 7 & $52 \pm 0.56^{+}$ & $65 \pm 0.29^{*}$ & $61 \pm 0.71^{++}$ & $75 \pm 0.73^{\star *}$ & $42 \pm 0.49^{\prime}$ & $49 \pm 0.92^{\#}$ & $51 \pm 0.56^{\prime \prime}$ & $70 \pm 0.49^{\text {\# }}$ \\
\hline 8 & $53 \pm 0.25^{+}$ & $67 \pm 0.47^{*}$ & $69 \pm 0.91^{++}$ & $77 \pm 0.72^{\star \star}$ & $48 \pm 0.29^{\prime}$ & $59 \pm 0.33^{\#}$ & $57 \pm 0.73^{\prime \prime}$ & $77 \pm 0.61^{\#}$ \\
\hline 9 & $53 \pm 0.37^{+}$ & $67 \pm 0.28^{*}$ & $69 \pm 0.77^{++}$ & $85 \pm 0.19^{* *}$ & $48 \pm 0.67^{\prime}$ & $59 \pm 0.82^{\#}$ & $57 \pm 0.40^{\prime \prime}$ & $77 \pm 0.48^{\#}$ \\
\hline 10 & $53 \pm 0.49^{+}$ & $67 \pm 0.76^{*}$ & $69 \pm 0.38^{++}$ & $85 \pm 0.38^{* *}$ & $48 \pm 0.94^{\prime}$ & $58 \pm 0.38^{\#}$ & $57 \pm 0.72^{1 /}$ & $77 \pm 0.38^{\#}$ \\
\hline
\end{tabular}

${ }^{*}$ P-values $<0.03$ with respect to the soluble $\beta$ galactosidase at $50^{\circ} \mathrm{C}$

${ }^{* *} \mathrm{P}$-values $<0.05$ with respect to the soluble $\beta$ galactosidase at $50^{\circ} \mathrm{C}^{++}$

${ }^{\#} \mathrm{P}$-values $<0.03$ with respect to the soluble $\beta$ galactosidase at $60^{\circ} \mathrm{C}^{\prime}$

${ }^{\prime \prime} \mathrm{P}$-values $<0.05$ with respect to the soluble $\beta$ galactosidase at $60^{\circ} \mathrm{C} "$

Milk and whey ( $500 \mathrm{ml}$, each) were treated independently with the soluble and the immobilized $\beta$ galactosidase in a stirred batch process at $50^{\circ} \mathrm{C} / 60$ ${ }^{\circ} \mathrm{C}$. The aliquots of $250 \mu \mathrm{l}$ were taken out at indicated time intervals for $10 \mathrm{~h}$. The hydrolysis of lactose was estimated by using assay procedure described in the text (Ansari and Husain 2010). 
oryzae $\beta$ galactosidase showed $100 \%$ activity at $\mathrm{pH} 4.6$ but its activity considerably decreased above $\mathrm{pH} 6 .{ }^{28}$. Despite the reduced hydrolytic activity shown by the immobilized $\beta$ galactosidase above $\mathrm{pH}$ 6.0, the rate of hydrolysis of milk lactose $(67 \%)$ can be considered quite satisfactory. Roy and Gupta (2003) had investigated that lactose hydrolysis by lactozym immobilized on cellulose beads took $48 \mathrm{~h}$ in a continuous batch mode ${ }^{29}$. According to recent reviews, some traditional enzymatic processes for milk lactose removal available in the market present a final hydrolytic value of $50-70 \%$ at reaction times larger than $18 \mathrm{~h}$. Thus, Con A layered calcium alginate-cellulose bead can be exploited commercially for lactose hydrolysis in milk and whey. Moreover, the enzyme activity of $\beta$ galactosidase decreased substantially at temperature higher than $50^{\circ} \mathrm{C}{ }^{30}$, thus a decreased lactose hydrolyzing activity was noticed at $60^{\circ} \mathrm{C}$ both in milk and whey in a stirred batch process (Table 3 ).

\section{Hydrolysis of lactose in continuous spiral-bed reactors}

Table 4 summarizes the influence of varied flow rates on the hydrolytic rate of lactose in a spiral bed reactor by taking same enzyme activity of the immobilized enzyme. It was observed that $95 \%$ and $90 \%$ of lactose was hydrolyzed by the immobilized $\beta$ galactosidase after 20 $\mathrm{d}$ and $40 \mathrm{~d}$, respectively when the flow rate was $20 \mathrm{ml} / \mathrm{h}$. At a flow rate of $30 \mathrm{ml} / \mathrm{h}$, the immobilized enzyme could attain $92 \%$ and $83 \%$ lactose hydrolysis after $20 \mathrm{~d}$ and $40 \mathrm{~d}$ of continuous operation of the reactor (Table 4). Mammarella and Rubiolo (2006) have earlier reported that higher lactose hydrolysis took place at lower flow rates $^{30}$. The results indicated that the extent of lactose hydrolysis might be simply controlled in a way of adjusting the flow rate of the continuous operation mode. Novalin et al. (2005) had reported $78 \%$ conversion of lactose in skimmed milk at flow rate of $9.9 \mathrm{~L} / \mathrm{h}$ at an enzyme activity of $120 \mathrm{U} / \mathrm{ml}$ and at a temperature of $23 \pm 2^{\circ} \mathrm{C}$ in a hollow fibre reactor ${ }^{26}$.

Since the immobilization procedure discussed in this manuscript is cheap and eliminates any complicated step while leading to high enzyme activity, it finds promising application in the continuous production of novel products in food and dairy industry.

Table 4. Lactose hydrolysis in continuous spiral bed reactors

\begin{tabular}{|c|c|c|}
\hline \multirow{2}{*}{ Number of days } & \multicolumn{2}{|c|}{ Lactose hydrolysis at different flow rates } \\
\cline { 2 - 3 } & $20 \mathrm{ml} / \mathrm{h}$ & $30 \mathrm{ml} / \mathrm{h}$ \\
\hline Control & $100^{+}$ & $100^{+*}$ \\
\hline 5 & $100 \pm 0.91^{*}$ & $100 \pm 0.73^{* *}$ \\
\hline 10 & $100 \pm 1.33^{*}$ & $95 \pm 0.95^{* *}$ \\
\hline 15 & $95 \pm 0.67^{*}$ & $92 \pm 0.96^{* *}$ \\
\hline 20 & $95 \pm 0.88^{*}$ & $92 \pm 1.03^{* *}$ \\
\hline 25 & $95 \pm 1.07^{*}$ & $92 \pm 1.38^{* *}$ \\
\hline 30 & $93 \pm 1.23^{*}$ & $88 \pm 1.46^{* *}$ \\
\hline 35 & $90 \pm 1.54^{*}$ & $86 \pm 1.39^{* *}$ \\
\hline 40 & $90 \pm 1.38^{*}$ & $83 \pm 1.54^{* *}$ \\
\hline
\end{tabular}

${ }^{*} \mathrm{P}<0.05$ with respect to control+

${ }^{* *} P<0.05$ with respect to control++

Hydrolysis of lactose in continuous reactors containing immobilized $\beta$ galactosidase (2520 U) was performed as described in the text (Ansari and Husain 2010).

\section{CONCLUSION}

Immobilized $\beta$ galactosidase was found to be remarkably stable against various physical and chemical denaturants and was successfully employed for the hydrolysis of lactose from milk and whey in a batch process. In view of its stability and utility in batch process, such preparation could be exploited for the continuous conversion of lactose from milk and whey for longer durations in a reactor in a more convenient and cheaper way.

\section{ACKNOWLEDGMENT}

The authors are thankful to the Council of Science and Technology, Lucknow, Uttar Pradesh for funding a project entitled "Immobilization of plant and fungal $\beta$ galactosidase by using bioaffinity supports - Its application in the hydrolysis of lactose in whey and milk."

\section{LITERATURE CITED}

1. Zhang, S., Gao, S \& Gao, G. (2010). Immobilization of $\beta$ galactosidase onto magnetic beads. Appl. Biochem. Biotechnol. 160, 1386-1393. DOI: 10.1007/s12010-009-8600-5.

2. Heyman, B. (2006). Lactose Intolerance in infants, children and adolescents. Pediatrics 118, 1279-1286. DOI: 10.1542/ peds.2006-1721.

3. Ansari, S.A. \& Husain, Q. (2010). Lactose hydrolysis by $\beta$ galactosidase immobilized on concanavalin A-cellulose in batch and continuous mode. J. Molec. Catal. B: Enzym. 6, 68-74. DOI: 10.1016/j.molcatb.2009.12.010.

4. Mateo, C., Palomo, J.M., Fernandez-Lorente, G., Guisan, J.M \& Fernandez-Lafuente, R (2007). Improvement of enzyme activity, stability and selectivity via immobilization techniques. Enzyme Microb. Technol. 40, 1451-1463. DOI: 10.1016/j.enzmictec.2007.01.018.

5. Ansari, S.A. \& Husain, Q. (2011). Immobilization of Kluyveromyces lactis $\beta$ galactosidase on concanavalin A layered $\mathrm{A} 12 \mathrm{O} 3$ nanoparticles-its application in biosensors. J. Molec. Catal. B: Enzym. 70, 119-126. DOI: 10.1016/j.molcatb.2011.02.016.

6. Husain, Q. (2010). $\beta$ Galactosidases and their potential applications. Crit. Rev. Biotechnol. 30, 41-62. DOI: 10.4061/2010/473137.

7. Betancor, L., Luckarift, R., Seo, H., Brand, O. \& Spain, J.C. (2008). Three-dimensional immobilization of $\beta$ galactosidase on a silicon surface. Biotechnol. Bioeng. 99, 261-267. DOI: $10.1002 /$ bit.21570.

8. Sun, S., Dong, L., Xu, X \& Shen, S. (2010). Immobilization of $\beta$ galactosidase from Aspergillus oryzae on macroporous poly GMA newly prepared. Int. J. Chem. 2, 89-96. DOI: 10.1016/ijc.2010.04.011.

9. Gurdas, S., Gulec, H.A. \& Mutlu, M. (2010). Immobilization of Aspergillus oryzae $\beta$ galactosidase onto Duolite A568 resin via simple adsorption mechanism. Food Bioproc. Technol. DOI 10.1007/s11947-010-0384-7.

10. Ansari, S.A., Husain, Q., Qayyum, S. \& Azam, A. (2011) Designing and surface modification of zinc oxide nanoparticles for biomedical applications. Food Chem. Toxicol. 2011 Sep;49(9):2107-15.

11. Husain, Q., Ansari, S.A., Alam, F. \& Azam, A. (2011) Immobilization of Aspergillus oryzae $\beta$ galactosidase on zinc oxide nanoparticles via simple adsorption mechanism. Int. J. Biol. Macromol. 49(1):37-43. DOI: 10.1016/j.ijbiomac.2011.03.011.

12. Bradford, M.M. (1976). A rapid and sensitive method for the quantification of microgram quantities of protein utilizing the principle of protein-dye binding. Anal. Biochem. 72, 248-255. DOI: 10.1016/S0076-6879(09)63008-1.

13. Lee, C.H., Oh, E., Kim, J. \& Ahn, D.J. (2008). Immobilization of polydiacetylene vesicles on cellulose acetate butyrate (CAB)-coated substrates for self-assembled supramolecular sensor arrays. Coll. Surf. A: Physicochem. Eng. Aspects. 313, 500-503. DOI: 10.1016/j.colsurfa.2007.04.174.

14. Prashanth, S.J. \& Mulimani, V.H. (2005). Soymilk oligosaccharides hydrolysis by Aspergillus oryzae $\beta$ galactosidase im- 
mobilized in calcium alginate. Process Biochem. 40, 1119-1205. DOI: $10.1016 /$ j.procbio.2004.04.011.

15. Smidsrod, O \& Skjak-Braek, G. (1990). Alginate as immobilization matrix for cells. Trends Biotechnol. 8, 71-78. DOI: 10.1016/0167-7799(90)90139-O.

16. Hennink, W.E. \& Nostrum, C.F.V. (2002). Novel crosslinking methods to design hydrogels. Adv. Drug. Deliv. 54, 13-36. DOI: $10.1016 /$ S0169-409X(01)00240-X.

17. Musthapa, S.M., Akhtar, S., Khan, A.A. \& Husain, Q. (2004). An economical, simple and high yield procedure for the immobilization/stabilization of peroxidases from turnip roots. J. Sc. Ind. Res. 63, 540-547. DOI: 10.1016/j.bioeng.2006.07.004.

18. Elnashar, M.M.M. \& Yassin, M.A. (2009). Lactose hydrolysis by $\beta$ galactosidase covalently immobilized to thermally stable biopolymers. Appl. Biochem. Biotechnol. 159, 426-37. DOI: 10.1007/s12010-008-8453-3.

19. Bayramoglu, G., Tunali, Y. \& Arica, M.Y. (2007). Immobilization of $\beta$ galactosidase onto magnetic poly (GMAMMA) beads for hydrolysis of lactose in bed reactor. Catalys. Commun. 8, 1094-1101. DOI: 10.1016/j.catcom.2006.10.029.

20. Ozdural, A.R., Tanyolac, D., Boyac, I.H. Mutlu, M \& Webb, C. (2003). Determination of apparent kinetic parameters for competitive product inhibition in packed-bed immobilized reactor. Biochem. Eng. J. 14, 27-36. DOI: 10.1016/ S1369-703X(02)00099-2.

21. Zhou, Q.Z., Chen, X.D \& Li, X. (2003). Kinetics of lactose hydrolysis by $\beta$ galactosidase of Kluyveromyces lactis immobilized on cotton. Biotechnol. Bioeng. 81, 127-133. DOI: 10.1002/bit.10414.

22. Sutendra, G., Wong, S., Fraser, M.E \& Huber, R.E. (2007). $\beta$ galactosidase (Escherichia coli) has a second catalytically important $\mathrm{Mg}^{+2}$ sites. Biochem. Biophys. Res. Comm. 352, 566-570. DOI: 10.1016/j.bbrc.2006.11.061.

23. Gaur, R., Pant, H., Jain, R. \& Khare, S.K. (2006) Galacto-oligosaccharide synthesis by immobilized Aspergillus oryzae $\beta$ galactosidase. Food Chem. 97, 426-430. DOI: 10.1016/j. foodchem.2005.05.020.

24. Haider, T. \& Husain, Q. (2008). Hydrolysis of milk/ whey lactose by $\beta$ galactosidase: a comparative study of stirred batch process and packed bed reactor prepared with calcium alginate entrapped enzyme. Chem. Eng. Proc.: Process Intens. 48, 576-580. DOI: 10.1016/j.cep.2008.02.007.

25. Diwedi, A. \& Kayastha, A.M. (2009). Stabilization of $\beta$ galactosidase (from peas) by immobilization onto amberlite MB-150 beads and its application in lactose hydrolysis. J. Agric. Food Chem. 57, 682-688. DOI: 10.1021/jf802573j.

26. Novalin, S., Neuhaus, W. \& Kulbe, K.D. (2005). A new innovative process to produce lactose reduced skim milk. J. Biotechnol. 119, 212-218. DOI: 10.1016/j.jbiotec.2005.03.018.

27. Li, X., Zhou, Q.Z.K. \& Chena, X.D. (2007). Pilot scale lactose hydrolysis using $\beta$ galactosidase immobilized on cotton fabric. Chem. Eng. Proc. 46, 497-500. DOI: 10.1016/j. cep.2006.02.011.

28. Tanriseven, A \& Dogan, S. (2002). A novel method for the immobilization of $\beta$ galactosidase. Process Biochem. 38, 27-30. DOI: 10.1016/S0032-9592(02)00049-3.

29. Roy, I. \& Gupta, M.N. (2003). Lactose hydrolysis by lactozym immobilized on cellulose beads in batch and fluidized modes. Process Biochem. 39, 325-332. DOI:10.1016/ S0032-9592(03)00086-4.

30. Mammarella, E.J. \& Rubiolo, A.C (2006). Predicting the packed bed reactor performance with immobilized microbial lactase. Process Biochem. 41, 1627-1636. DOI: 10.1016/j. procbio.2006.03.009. 